\title{
Hubungan Hygiene Makanan, Sumber Air dan Personal Hygiene dengan Kejadian Diare pada Anak
}

\author{
C.Suraya \\ Program Studi Ilmu Keperawatan, STIK Bina Husada Palembang \\ Email Korespondensi: citra_suraya@yahoo.com
}

\section{Kata kunci : \\ Hygiene Makanan; Sumber Air; Personal Hygiene; Diare; \\ Keywords : Food Hygiene; Water Sourch; Personal Hygiene; Diarrhea;}

Info Artikel:

Tanggal dikirim:

11 September 2019

Tanggal direvisi:

4 Oktober 2019

Tanggal diterima : 8 Oktober 2019

DOI Artikel: 10.33862/citradelima. v3i2.78

Halaman: 94 - 100

\begin{abstract}
Abstrak
Semakin berkembangnya suatu Negara maka semakin besar juga produksi yang dihasilkannya. Hal negatif yang bisa timbul dari berkembangnya suatu negara salah satunya adalah faktor pencemaran suatu lingkungan dan air, makanan instan dan penurunan kedisiplinan individu dalam memilih kehidupan sehat dan bersih. Berdasarkan prevalensi menurut World Health Organization (WHO) 2018 bahwa terjadi peningkatan sebanyak $68 \%$ kejadian diare pada Negara berkembang. Penilitian ini bertujuan untuk mengetahui faktor-faktor yang berhubungan dengan kejadian diare pada anak di Rumah Sakit. Penelitian ini menggunakan desain kuantitatif dengan pendekatan cross sectional. Penelitian ini dilakukan di Instalasi rawat inap rumah sakit Rumah Sakit. Sampel pada penelitian ini adalah pasien anak yang dirawat di salah satu rumah sakit swasta Palembang pada bulan Januari sampai dengan Februari Tahun 2019, yang berjumlah 30 orang. Teknik pengambilan sampel pada penelitian ini menggunakan accidental sampling. Teknik pengumpulan data yang dilakukan dengan wawancara menggunakan kuesioner. Penelitian ini menunjukkan ada hubungan hygiene makanan dengan diare pada anak $(\rho=0,005)$. Ada hubungan sumber air dengan diare pada anak $(\rho=0,008)$. Ada hubungan personal hygiene dengan diare pada anak $(\rho=0,024)$. Kepada petugas rumah sakit diharapkan untuk lebih menggalakkan penyuluhan terkait faktor risiko penyakit diare pada anak. Upaya penyuluhan hendaknya dilakukan secara terus menerus sampai masyarakat khususnya ibu anak bisa mamahami akibat dari personal hygiene dan sanitasi makanan yang tidak Baik.
\end{abstract}

\section{Relationship of Food Hygiene Water Source and Personal Hygiene with the Incidence of Diarrhea in Children}

\footnotetext{
Abstract

The more developed a country, the higher the product it produces. One of the negative things that can arise from the development of a country is one of them is the pollution factor of an environment and water, instant food, and a decrease in an individual discipline in choosing a healthy and clean life. Based on prevalence, according to the World Health Organization (WHO) 2018 that there is a $68 \%$ increase in the incidence of diarrhea in developing countries. This study aims to determine the factors associated with the prevalence of diarrhea in children in the hospital. This research uses quantitative design with a cross-sectional approach. This research was conducted at the hospital inpatient hospital installation. The sample in this study were pediatric patients treated at one of Palembang's hospitals from January to February 2019, totaling 30 people. The sampling technique in this study uses accidental sampling. Data collection techniques were carried out by interview using a questionnaire. Results: This study showed a relationship between food hygiene and diarrhea in children $(\rho=0.005)$. There is a relationship between water sources and diarrhea in children $(\rho=0.008)$. There is a relationship of personal hygiene with diarrhea in children $(\rho=0.024)$. To hospital staff to further promote counseling related to risk factors for diarrheal disease in children. Counseling efforts should be carried out continuously until the community, especially mothers of children, can understand the consequences of bad personal hygiene and food sanitation.
} 


\section{PENDAHULUAN}

Pembangunan kesehatan di Indonesia merupakan bagian intergral dan terpenting dari pembangunan nasional. Tujuan diselenggarakannya pembangunan kesehatan untuk meningkatkan kesadaran, kemauan dan kemampuan hidup sehat bagi setiap orang agar terwujud derajat kesehatan masyarakat yang optimal yang dapat mencegah berbagai penyakit terutama bagi anak-anak yang sangat rentan terkena penyakit (Ferdianto, 2014).

Diare adalah penyakit utama kedua yang paling sering menyerang anak- anak (flu adalah yang pertama), sekitar separuh dari semua kasus diare terjadi dalam 3 sampai 4 bulan pada puncak musim dingin. Angka penyakit tertinggi terjadi pada anak antara usia 3 bulan sampai 2 tahun. Rotavirus merupakan suatu agens kausatif diare akut yang masuk rumah sakit sekitar 50\% antara 5\% dan 10\% anak yang masuk rumah sakit adalah karena terinfeksi adenovirus enterik dan $15 \%$ yang lain disebabkan oleh bakteri (Betz dan Sowden, 2013).

Diare merupakan penyebab umum kematian di negara berkembang, penyebab kedua kematian bayi di seluruh dunia dan penyebab nomor satu kematian balita (bawah lima tahun) seluruh dunia. Hilangnya cairan karena diare dapat menyebabkan dehidrasi dan gangguan elektrolit seperti kekurangan kalium atau ketidakseimbangan garam lainnya. Menurut World Health Organization (WHO) pada tahun 2009, diare diperkirakan telah menyebabkan 1,1 juta kematian path orang dewasa dan 1,5 juta kematian pada anak bawah lima tahun (balita). Data dari The United Nations Children's Fund (UNICEF) tercatat setiap 30 detik ada satu balita meninggal dunia karena diare (Sumampouw, 2017).

Penyakit Diare merupakan penyakit endemis di Indonesia dan juga merupakan penyakit potensial Kejadian Luar Biasa (KLB) yang sering disertai dengan kematian. Target cakupan pelayanan penderita Diare semua umur (SU) yang datang ke sarana kesehatana dalah $10 \%$ dari perkiraan jumlah penderita Diare SU (Insidens Diare SU dikali jumlah penduduk di satu wilayah kerja dalam waktu satu tahun). Tahun 2016 jumlah penderita diare SU yang dilayani di sarana kesehatan sebanyak 3.176.079 penderita dan terjadi peningkatan pada tahun 2017 yaitu menjadi 4.274.790 penderita atau $60,4 \%$ dari perkiraan diare di sarana kesehatan. Insiden diare semua umur secara nasional adalah 270/1.000 penduduk. Target cakupan pelayanan penderita Diare Balita yang datang ke sarana kesehatan adalah $10 \%$ dari perkiraan jumlah penderita Diare Balita (Insidens Diare Balita dikali jumlah Balita di satu wilayah kerja dalam waktu satu tahun).

Berdasarkan data Dinas Kesehatan Kota Palembang, jumlah diare di kota Palembang pada tahun 2015 sebanyak 38.721 kasus, pada tahun 2016 sebanyak 37.896 kasus dan pada tahun 2017 sebanyak 41.957 kasus (Dinkes Palembang, 2018).

Berdasarkan data rekam medic Rumah Sakit Islam Siti Khadijah Palembang, angka kejadian diare pada tahun 2016 sebanyak 413 kasus, pada tahun 2017 sebanyak 385 kasus, pada tahun 2018 sebanyak 521 kasus dan pada periode Bulan Januari-Maret Tahun 2019 sebanyak 130 kasus.

Negara berkembang diserang oleh beragam jenis penyakit bawaan makanan. Dengan sistem pelaporan yang buruk atau tidak ada sama sekali pada kebanyakan negara berkembang, data statistik yang bisa diandalkan tentang penyakit ini tidak tersedia sehingga besaran insidensinya tidak dapat diperkirakan. Akan tetapi, beratnya situasi ini dapat dipahami dengan melihat angka prevalensi penyakit diare yang tinggi di kalangan bayi dan anak-anak. Setiap tahun, terdapat sekitar 1500 juta kejadian diare pada balita, dan sebagai akibat langsungnya lebih dan 3 juta anak meninggal. Secara tidak langsung, jutaan anak lain meninggal akibat efek gabungan yang ditimbulkan oleh diare dan malnutrisi. Sebelumnya ada dugaan bahwa persediaan air yang terkonta minasi merupakan sumber utama patogen yang menyebabkan diare, tetapi saat ini diketahui bahwa makanan memainkan peranan yang sama pentingnya. Menurut perkiraan, sekitar $70 \%$ kasus penyakit diare terjadi karena makanan yang terkontaminasi. Kejadian ini juga mencakup pemakaian air minum dan air untuk menyiapkan makanan. Perlu dipethatikan bahwa peranan air dan makanan dalam penularan penyakit diare tidak dapat diabaikan karena air merupakan unsur yang ada dalam makanan maupun minuman dan juga digunakan untuk mencuci tangan, bahan makanan, serta peralatan untuk memasak atau makan. Jika air terkontaminasi dan hygiene yang baik tidak dipraktikkan, makanan yang dihasilkan kemungkinan besar juga terkontaminasi (Hartono, 2014).

http://jurnalilmiah.stikescitradelima.ac.id/index.php/JI Vol.3,No.2, Januari 2020 
Berdasarkan hal tersebut diatas, maka peneliti tertarik untuk melakukan penelitian tentang faktorfaktor yang berhubungan dengan kejadian diare pada anak di Rumah Sakit Islam Siti Khadijah Palembang Tahun 2019.

\section{METODE}

Penelitian ini menggunakan desain penelitian kuantitatif survey analitik dengan pendekatan desain cross sectional. Hipotesis dalam penelitian ini yaitu ada hubungan hygiene makanan, sumber air, personal hygiene dengan kejadian diare pada usia 0-12 bulan.

Sampel di dalam penelitian ini adalah ibu yang memiliki anak dirawat inap di instalasi rawat inap salah satu rumah sakit swasta di Palembang tahun 2019, yang berjumlah 30 responden. Penelitian dilaksanakan pada tanggal 02 Januari sampai dengan 26 Februari 2019.

Analisa data dilakukan dalam dua tahap yaitu dengan analisis univariat dan bivariat. Analisa univariat yang dilakukan dengan melihat distribusi frekuensi dari masing-masing kategori variabel independen dan variabel dependen. Analisis statistik secara bivariate pada penelitian ini menggunakan uji chi square. Alat pengumpulan data dalam penelitian ini menggunakan kuesioner yang meliputi pertanyaan tentang faktorfaktor yang berhubungan dengan kejadian diare pada anak berbentuk lembar cek list dengan metode observasi. Kuesioner yang digunakan sebelumnya telah diujikan validitas dan reliabilitas. Analisa yang dilakukan dengan melihat distribusi frekuensi dan persentase Pada penelitian ini analisa univariat dilakukan untuk mendapatkan distribusi frekuensi variabel tiap-tiap variable dan analisa bivariat dilakukan untuk melihat hubungan dengan kejadian diare pada anak.

\section{HASIL DAN PEMBAHASAN}

Analisa Univariat

Tabel 1. Distribusi Frekuensi Responden Berdasarkan Hygiene Makanan

\begin{tabular}{lcc}
\hline \multicolumn{1}{c}{ Hygiene Makanan } & Jumlah & \% \\
\hline Kurang & 13 & 43,3 \\
\hline Baik & 17 & 56,7 \\
\hline
\end{tabular}

Dari hasil penelitian yang dilakukan didapatkan 30 reponden sebagian besar memiliki hygine makanan baik sebanyak $56,7 \%$.

Tabel 2. Distribusi Frekuensi Responden Berdasarkan Sumber Air

\begin{tabular}{lcc}
\multicolumn{1}{r}{ Sumber Air } & Jumlah & \% \\
\hline Non PAM & 11 & 36,7 \\
\hline PAM & 19 & 63,3 \\
\hline
\end{tabular}

Dari hasil penelitian yang dilakukan didapatkan dari 30 responden sebagian besar menggunakan sumber air PAM sebanyak 63,3\%.

Tabel 3. Distribusi Frekuensi Responden Berdasarkan Personal Hygiene

\begin{tabular}{lcc}
\multicolumn{1}{c}{ Personal Hygiene } & Jumlah & \% \\
\hline Kurang & 19 & 63,3 \\
\hline Baik & 11 & 36,7 \\
\hline
\end{tabular}

Dari hasil penelitian yang dilakukan didapatkan dari 30 responden sebagian besar memiliki personal hygiene kurang sebanyak 63,3\%.

Tabel 4. Distribusi Frekuensi Responden Berdasarkan Diare

\begin{tabular}{|c|c|c|}
\hline Diare & Jumlah & $\%$ \\
\hline Ya & 17 & 56,7 \\
\hline Tidak & 13 & 43,3 \\
\hline
\end{tabular}

Dari hasil penelitian yang dilakukan didapatkan dari 30 responden sebagian besar mengalami diare sebanyak $56,7 \%$.

Analisa Bivariat

Tabel 1. Hubungan Hygiene Makanan Dengan Diare Pada Anak

\begin{tabular}{|c|c|c|c|c|c|}
\hline \multirow{3}{*}{$\begin{array}{l}\text { Hygiene } \\
\text { makanan }\end{array}$} & \multicolumn{4}{|c|}{ Diare } & \multirow{3}{*}{ P-Value } \\
\hline & \multicolumn{2}{|c|}{ Ya } & \multicolumn{2}{|c|}{ Tidak } & \\
\hline & $\mathrm{n}$ & $\%$ & $\mathrm{n}$ & $\%$ & \\
\hline Kurang & 11 & 84,6 & 2 & 15,4 & \multirow{3}{*}{0,020} \\
\hline Baik & 6 & 35,3 & 11 & 64,7 & \\
\hline Jumlah & 17 & 56,7 & 13 & 43,3 & \\
\hline
\end{tabular}

Dari hasil penelitian yang dilakukan didapatkan responden yang mengalami diare dan memiliki hygiene makanan kurang sebanyak 11 orang $(84,6 \%)$, lebih banyak jika dibandingkan dengan responden yang mengalami diare dan memiliki hygiene makanan baik yaitu sebanyak 6 orang $(35,3 \%)$. Hasil uji statistik chisquare didapatkan $\rho$ value $=0,020$, yang jika dibandingkan dengan nilai $\alpha=0,05$, maka $\rho$ value $\leq$ 0,05 . Ini berarti ada hubungan hygiene makanan 
dengan diare pada anak di Rumah Sakit Islam Siti Khadijah Palembang Tahun 2019.

\section{Tabel 2. Hubungan Sumber Air Dengan Diare Pada Anak}

\begin{tabular}{|c|c|c|c|c|c|}
\hline \multirow{3}{*}{$\begin{array}{c}\text { Sumber } \\
\text { Air }\end{array}$} & \multicolumn{4}{|c|}{ Diare } & \multirow{3}{*}{ P-Value } \\
\hline & \multicolumn{2}{|c|}{ Ya } & \multicolumn{2}{|c|}{ Tidak } & \\
\hline & n & $\%$ & $\mathrm{n}$ & $\%$ & \\
\hline NON & 10 & 90,9 & 1 & 9,1 & \multirow{4}{*}{0,013} \\
\hline PAM & & & & & \\
\hline PAM & 7 & 36,8 & 12 & 63,2 & \\
\hline Jumlah & 17 & 56,7 & 13 & 43,3 & \\
\hline
\end{tabular}

Dari hasil penelitian yang dilakukan didapatkan responden yang mengalami diare dan menggunakan sumber air non PAM sebanyak 10 orang $(90,9 \%)$, lebih banyak jika dibandingkan dengan responden yang mengalami diare dan menggunakan sumber air PAM yaitu sebanyak 1 orang $(9,1 \%)$. Hasil uji statistik chisquare didapatkan $\rho$ value $=0,013$, yang jika dibandingkan dengan nilai $\alpha=0,05$, maka $\rho$ value $\leq$ 0,05 . Ini berarti ada hubungan sumber air dengan diare pada anak di Rumah Sakit Islam Siti Khadijah Palembang Tahun 2019.

Tabel 3. Hubungan Personal Hygiene Dengan Diare Pada Anak

\begin{tabular}{lccccc}
\hline \multirow{2}{*}{$\begin{array}{l}\text { Personal } \\
\text { Hygiene }\end{array}$} & \multicolumn{4}{c}{ Diare } & \multirow{2}{*}{ P-Value } \\
\cline { 2 - 4 } & \multicolumn{2}{c}{ Ya } & \multicolumn{2}{c}{ Tidak } & \\
\cline { 2 - 5 } & $\mathbf{n}$ & $\mathbf{\%}$ & $\mathbf{n}$ & $\mathbf{\%}$ & \\
\hline Kurang & 14 & 73,3 & 5 & 26,3 & \\
\hline Baik & 3 & 27,3 & 8 & 72,7 & 0 \\
\hline Jumlah & 17 & 56,7 & 13 & 43,3 & \\
\hline
\end{tabular}

Dari hasil penelitian yang dilakukan didapatkan responden yang mengalami diare dan memiliki personal hygiene kurang sebanyak 14 orang $(73,7 \%)$, lebih banyak jika dibandingkan dengan responden yang mengalami diare dan memiliki personal hygiene baik yaitu sebanyak 3 orang (27,3\%). Hasil uji statistik chi-square didapatkan $\rho$ value $=0,037$, yang jika dibandingkan dengan nilai $\alpha=0,05$, maka $\rho$ value $\leq$ 0,05 . Ini berarti ada hubungan personal hygiene dengan diare pada anak di Rumah Sakit Islam Siti Khadijah Palembang Tahun 2019.

\section{Analisa Univariat \\ Hygiene Makanan}

Berdasarkan hasil penelitian didapatkan bahwa responden yang memiliki hygiene makanan baik adalah lebih banyak.

Sejalan dengan penelitian Ferdianto (2014) bahwa sebagian besar responden berkategorik baik dalam hygiene makanan. Salah satu penilaian dalam analisis gambarannya adalah responden mampu melakukan dan menerapkan mencuci tangan yang tepat sebelum menyentuh makanan.

Berdasarkan hasil penelitian serta teori yang ada maka peneliti berasumsi bahwa pada dasarnya sebagian besar responden memiliki hygiene makanan yang baik. Hal-hal yang sering dilakukan dalam penanganan makan yaitu dengan mencuci tangan sebelum makan dan memasak sendiri makanan sehari-hari.

\section{Sumber Air}

Berdasarkan hasil penelitian didapatkan bahwa responden lebih banyak yang menggunakan sumber air PAM.

Menurut PMI (2006), air minum adalah air yang kualitasnya memenuhi syarat kesehatan, dapat langsung diminum, terbebas dari bibit penyakit dan zat kimia berlebihan, tidak bersifat asam maupun basa. Air minum dapat menularkan penyakit, air yang terkontaminasi tinja sering mengakibatkan epidemik yang eksplosif. Penyakit menular yang disebarkan melalui air secara langsung di masyarakat seringkali dinyatakan sebagai penyakit bawaan air atau water borne disease. Penyakit-penyakit ini dapat menyebar apabila mikroorganisme penyebabnya dapat masuk ke dalam sumber air yang digunakan manusia dalam memenuhi kebutuhannya sehari-hari. Sebelum dikonsumsi air minum harus direbus terlebih dahulu hingga mendidih, disimpan dengan tertutup rapat dan sebaiknya tidak lebih dari 24 jam setelah dimasak.

Berdasarkan hasil penelitian serta teori yang ada maka peneliti berasumsi bahwa dalam penelitian ini responden yang menggunakan sumber air non PAM menggunakan sumur gali. Meskipun mata air dan sumur gali tidak mendapatkan pengolahan khusus seperti air PDAM maupun air kemasan, sebagian besar responden memilih mata air dan sumur gali sebagai sumber air minum.

http://jurnalilmiah.stikescitradelima.ac.id/index.php/JI Vol.3,No.2, Januari 2020 


\section{Personal Hygiene}

Berdasarkan hasil penelitian didapatkan bahwa responden yang memiliki personal hygiene kurang sebanyak 19 orang $(63,3 \%)$, lebih banyak jika dibandingkan dengan responden yang memiliki personal hygiene baik yaitu sebanyak 11 orang $(36,7 \%)$.

Menurut PMI (2006), personal hygiene yang rendah dalam kehidupan sehari-hari seperti tidak mencuci tangan setelah buang air besar, tidak mencuci tangan sebelum makan serta kebiasaan tidak mencuci bahan makanan mentah yang akan dimakan langsung. Tujuan mencuci tangan adalah membersihkan tangan dari segala kotoran, mencegah penularan penyakit, dan melatih kebiasaan yang baik.

Berdasarkan hasil penelitian serta teori yang ada maka peneliti berasumsi bahwa kebiasaan yang berhubungan dengan kebersihan perorangan itu merupakan salah satu upaya dalam pencegahan terhadap kejadian diare pada diri sendiri.

\section{Kejadian Diare}

Berdasarkan hasil penelitian didapatkan bahwa responden lebih banyak mengalami diare.

Menurut Sodikin (2014), diare merupakan proses inflamasi dalam lambung dan usus, walaupun pada beberapa kasus tidak selalu demikian seperti pada kondisi seperti kolera atau apa yang dihasilkan oleh E.coli, di mana mukosa usus dan gaster secara struktural ada kecendrungan normal.

Berdasarkan hasil penelitian serta teori yang ada maka peneliti berasumsi bahwa responden yang mengalami diare mungkin disebabkan oleh faktor lain selain kebersihan orangtua dalam menjaga kebersihan makanan seperti anak yang alergi terhadap suatu makanan atau infeksi oleh bakteri tertentu sehingga bisa menyebabkan diare.

\section{Analisa Bivariat}

Hubungan Hygiene Makanan dengan Diare Pada Anak

Dari hasil penelitian yang dilakukan didapatkan bahwa responden lebih banyak yang mengalami diare dan memiliki hygiene makanan kurang. Hasil uji statistik chi square didapatkan $\rho$ value $=0,020$, yang jika dibandingkan dengan nilai $\alpha=0,05$, maka $\rho$ value $\leq 0,05$, sehingga Hipotesis Nol (Ho) ditolak, Hipotesis Alternatif (Ha) diterima. Ini berarti ada hubungan hygiene makanan dengan diare pada anak di Rumah Sakit Islam Siti Khadijah Palembang Tahun 2019. Dengan demikian hipotesis yang menyatakan ada hubungan hygiene makanan dengan diare pada anak terbukti secara statistik.

Penelitian yang tidak sejalan pada Hygiene makanan di Rumah Sakit Islam Siti Khadijah Palembang termasuk dalam kategori baik, hal ini dikarenakan responden yang sebagian besar telah mengetahui tentang hygiene makanan yang baik sehingga ibu anak dapat memilih makanan yang baik untuk dikonsumsi dan sesuai dengan kebutuhan anak. Selain itu hygiene makanan yang baik ditunjang dengan pemahaman ibu anak yang baik tentang sanitasi makanan. Selain itu hasil penelitian menunjukkan bahwa terdapat ibu anak yang memiliki hygiene makanan baik namun balita mengalami diare. Hal ini disebabkan karena kejadian diare pada anak tidak sepenuhnya dipengaruhi oleh hygiene makanan dimana hygiene makanan hanya sebagai faktor resiko. Adapun faktor risiko kejadian diare pada balita antara lain: personal hygiene dan sarana air bersih yang digunakan dalam kegiatan sehari-hari.

Berdasarkan hasil penelitian serta teori yang ada dapat dibuat kesimpulan bahwa tingkat kejadian diare akibat hyegene makanan adalah dipengaruhi dari tingkat pengetahuan seseorang. Jika seseorang mengetahui akan pentingnya hyegene makanan bagi dirinya maka dia akan mampu menjaga kebersihan setiap makanannya.

\section{Hubungan Sumber Air dengan Diare Pada Anak}

Dari hasil penelitian yang dilakukan didapatkan bahwa responden lebih banyak yang mengalami diare dan menggunakan sumber air non PAM. Hasil uji statistik chi square didapatkan $\rho$ value $=0,013$, yang jika dibandingkan dengan nilai $\alpha=0,05$, maka $\rho$ value $\leq 0,05$, sehingga Hipotesis Nol (Ho) ditolak, Hipotesis Alternatif (Ha) diterima. Ini berarti ada hubungan sumber air dengan diare pada anak di Rumah Sakit.

Sejalan dengan teori yang dikemukakan oleh Chandra (2014) yang menyatakan bahwa, air merupakan zat yang paling penting dalam kehidupan setelah udara. Sekitar tiga per empat bagian dari tubuh

http://jurnalilmiah.stikescitradelima.ac.id/index.php/JI Vol.3,No.2, Januari 2020 
kita terdiri dari air dan tidak seorangpun dapat bertahan hidup lebih dari 4-5 hari tanpa minum air. Selain itu, air juga dipergunakan untuk memasak, mencuci, mandi, dan membersihkan kotoran yang ada di sekitar rumah. Air juga digunakan untuk keperluan industri, pertanian, pemadam kebakaran, tempat rekreasi, transportasi, dan lain-lain. Penyakit-penyakit yang menyerang manusia dapat juga ditularkan dan disebarkan melalui air. Kondisi tersebut tentunya dapat menimbulkan wabah penyakit dimanamana.

Hasil penelitian ini tidak jauh berbeda dari penelitian yang dilakukan oleh Raharjo dan Budiyono (2018), tentang hubungan kualitas air minum dengan kejadian diare pada balita di Wilayah Kerja Puskesmas Banyuasin Kecamatan Loano Kabupaten Purworejo, didapatkan hasil analisis chi-square ada hubungan diare dengan sumber air utama sebesar 0,007 $(\mathrm{p}<0,05)$ sedangkan hubungan diare dengan kualitas fisik air sebesar $\mathrm{p}=0,005(\mathrm{p}<0,05)$.

Berdasarkan hasil penelitian serta teori yang ada dapat dibuat kesimpulan bahwa meskipun mata air dan sumur gali tidak mendapatkan pengolahan khusus seperti air PDAM maupun air kemasan, sebagian besar responden memilih mata air dan sumur gali sebagai sumber air minum. Sumber air minum diolah meliputi air kemasan dan PDAM, sedangkan yang tidak diolah meliputi mata air, sumur gali, sumur bor, sungai, dan air hujan. diare sebanyak 23 balita (36,5\%). Sumber air minum yang akan dikonsumsi sebelumnya telah dimasak hingga mendidih walaupun sumber air minum tidak mendapatkan proses pengolahan sebelumnya. Proses pengolahan yang dimaksud yaitu proses penyaringan, pengendapan, dan disinfeksi. Meski sudah dimasak hingga mendidih, namun dapat terjadi pencemaran kembali saat melakukan penyimpanan air minum ke pencucian, sehingga air sisa galon yang tergenang pada dispenser dapat menjadi tempat pertumbuhan bakteri serta udara sekitar yang mengandung mikroorganisme dapat berkontak dengan air tersebut sehingga memperbesar terjadinya pencemaran kembali. Udara mengandung bakteri gram negative dimana bakteri tersebut lebih mudah beradaptasi dengan lingkungan sekitar sehingga untuk terjadinya pertumbuhan dan perkembangbiakan bakteri lebih cepat daripada bakteri gram positif.

Hubungan Personal Hygiene dengan Diare Pada Anak
Dari hasil penelitian yang dilakukan didapatkan bahwa lebih banyak responden yang mengalami diare dan memiliki personal hygiene kurang. Hasil uji statistik chi square didapatkan $\rho$ value $=0,037$, yang jika dibandingkan dengan nilai $\alpha=0,05$, maka $\rho$ value $\leq 0,05$, sehingga Hipotesis Nol (Ho) ditolak, Hipotesis Alternatif (Ha) diterima. Ini berarti ada hubungan personal hygiene dengan diare pada anak di Rumah Sakit Islam Siti Khadijah Palembang Tahun 2019. Dengan demikian hipotesis yang menyatakan ada hubungan personal hygiene dengan diare pada anak terbukti secara statistik.

Sejalan dengan teori yang dikemukakan oleh Saputra (2013) yang menyatakan bahwa, personal hygiene (kebersihan diri) merupakan perawatan diri yang dilakukan untuk memelihara kebersihan dan kesehatan diri sendiri baik secara fisik maupun mental Tingkat kebersihan diri seseorang umumnya dilihat dari penampilan yang bersih dan rapi serta upaya yang dilakukan seseorang untuk menjaga kebersihan dan kerapian tubuhnya setiap hari. Kebersihan merupakan langkah awal dalam mewujudkan kesehatan diri karena tubuh yang bersih meminimalkan risiko seseorang terjangkit suatu penyakit, terutama penyakit yang berhubungan dengan kebersihan diri yang buruk.

Berdasarkan hasil penelitian serta teori yang ada dapat dibuat kesimpulan bahwa hygiene merupakan suatu tindakan untuk memelihara kebersihan dan kesehatan seseorang untuk kesejahteraan, baik fisik maupun psikis. Dalam kehidupan sehari-hari kebersihan merupakan hal yang sangat penting dan harus diperhatikan karena kebersihan diri akan mempengaruhi kesehatan, kenyamanan, keamanan, dan kesejahteraan diri seseorang. Kebiasaan yang berhubungan dengan kebersihan perorangan yang penting dalam penularan kuman diare adalah mencuci tangan. Mencuci tangan menggunakan sabun terutama sesudah buang air besar, sesudah membuang tinja, sesudah buang air besar, sebelum menyiapkan makanan mempunyai dampak dalam diare.

\section{SIMPULAN}

Distribusi frekuensi responden yang memiliki hygiene makanan baik sebanyak 17 orang $(56,7 \%)$ dan responden yang memiliki hygiene makanan kurang yaitu sebanyak 13 orang (43,3\%). Distribusi frekuensi responden yang menggunakan sumber air PAM sebanyak 19 orang $(63,3 \%)$ dan responden yang menggunakan sumber air non PAM yaitu sebanyak 11

http://jurnalilmiah.stikescitradelima.ac.id/index.php/JI Vol.3,No.2, Januari 2020 
orang $(36,7 \%)$. Distribusi frekuensi responden yang memiliki personal hygiene kurang sebanyak 19 orang $(63,3 \%)$ dan responden yang memiliki personal hygiene baik yaitu sebanyak 11 orang (36,7\%). Distribusi frekuensi responden yang mengalami diare sebanyak 17 orang $(56,7 \%)$ dan responden yang tidak mengalami diare yaitu sebanyak 13 orang $(43,3 \%)$. Ada hubungan hygiene makanan dengan diare pada anak di Rumah Sakit Tahun $2019(\rho=0,005)$. Ada hubungan sumber air dengan diare pada anak di Rumah Sakit Tahun $2019(\rho=0,008)$. Ada hubungan personal hygiene dengan diare pada anak di Rumah Sakit Tahun $2019(\rho=0,024)$.

\section{DAFTAR PUSTAKA}

Betz dan Sowden, 2013. Buku Saku Keperawatan Pediatri. Jakarta. EGC

Chandra, 2014. Pengantar Kesehatan Lingkungan. Jakarta. EGC

Dinkes Kota Palembang, 2018. Profil Kesehatan Kota Palembang Tahun 2017

Ferdianto, 2014. Peran Posyandu Dalam Pembangunan Manusia. Didapatkan dari www.kesehatan.kompasiana.com. Diakses tanggal : 15 April 2019

Hartono, 2014. Penyakit Bawaan Makanan. Jakarta. EGC

Kemenkes RI, 2018. Profil Kesehatan Indonesia Tahun 2017. Jakarta. Kementerian Kesehatan RI

Marsanti dan Widiarini, 2018. Buku Ajar Higiene Sanitasi Makanan. Ponorogo. Uwais Inspirasi Indonesia

PMI, 2006. Pedoman Perawatan Keluarga. Jakarta. PMI

Raharjo dan Budiyono, 2018. Hubungan Kualitas Air Minum Dengan Kejadian Diare Pada Balita di Wilayah Kerja Puskesmas Banyuasin Kecamatan Loano Kabupaten Purworejo. Jurnal. Fakultas

KesehatanMasyarakatUniversitas

Diponegorohttp://eprints.undip.ac.id/ 47026/1/5489.pdf
Saputra, 2013. Pengantar Kebutuhan Dasar Manusia. Jakarta. Binarupa Aksara

Sodikin, 2014. Asuhan Keperawatan anak Gangguan Sistem Gastrointestinal dan Hepatobilier. Jakarta. Salemba Medika

Sumampouw, 2017. Diare Balita. Yogyakarta Deep Publish

Susanti, Hariyanto dan Adi, 2017. Hubungan Pengetahuan Ibu Tentang Hygiene Makanan Dengan Kejadian Diare Pada Bayi di Wilayah Kerja Posyandu Melati Kelurahan Tlogomas Malang. Jurnal. Program Studi Ilmu Keperawatan Fakultas Ilmu Kesehatan Universitas Tribhuwana Tunggadewi.Vol2,No1(2017) https://publikasi.unitri.ac.id/index.ph p/fikes/article/view/156 